\title{
IDENTIFIKASI KEJADIAN OBESITAS PADA LANSIA DI WILAYAH KERJA PUSKESMAS SIDOREJO KIDUL
}

\section{IDENTIFICATION OF OBESITY IN ELDERY IN WORKING AREAS OF PUSKESMAS SIDOREJO KIDUL}

\author{
Kristiawan P. A. Nugroho ${ }^{1 *}$, R. L. N. K Retno Triandhini ${ }^{2}$, Shara Minantri Haika ${ }^{3}$ \\ ${ }^{* 1}$ Program Studi Gizi, Fakultas Kedokteran dan IImu Kesehatan, Universitas Kristen Satya Wacana, \\ email : kristiawan.nugroho@uksw.edu, Indonesia \\ ${ }^{2}$ Program Studi Gizi, Fakultas Kedokteran dan IImu Kesehatan, Universitas Kristen Satya Wacana, \\ email : retno.triandhini@uksw.edu, Indonesia \\ ${ }^{3}$ Program Studi Gizi, Fakultas Kedokteran dan Ilmu Kesehatan, Universitas Kristen Satya Wacana, \\ email : sharaminantri14@gmail.com, Indonesia
}

\begin{abstract}
Background: Obesity is one of serious nutritional problems in Indonesia. Based on health profile of Central Java in 2015 , Salatiga has the highest percentage of obesity problem counted $71.8 \%$ of 561,621 cases. Obesity in elderly are mostly caused by degenerative function of organs which lead to diabetes, hypertension, dyslipidemia, and heart disease.

Objective: This study aimed to identify elders' eating habits, their knowledge of obesity and to identify correlation between the knowledge and obesity.

Methods: Observational survey technique by using interview, observation, and questionnaire method was employed to 89 respondents. Correlation among all variables was measured by utilizing Pearson Correlation Coefficient.

Results: As many as $10.8 \%$ of elderly are obese. Their knowledge regarding Pedoman Gizi Seimbang (PGS) is in sufficient category $(69,7 \%)$. The respondents had unhealthy eating habit by consuming high carbohydrates and fats which might influence the incidence of obesity. There is no statistical correlation between respondents' knowledge and eating habits $(r=-0.37, p>0,05)$.

Conclusion: Even though there is no statistical correlation between respondents' knowledge and their eating habits, there might be other factors such as age, sex, education, occupation, socio-economic, and family roles that need to be investigated as influencing factors to the obesity incidence in this population.
\end{abstract}

Keywords: obesity, elderly, knowledge, dietary history, Salatiga

\section{PENDAHULUAN}

Masalah kesehatan dalam bidang gizi masih menjadi fokus utama bagi negara maju dan berkembang. Sampai saat ini Indonesia masih berfokus dalam masalah gizi, yaitu gizi kurang dan gizi lebih. Obesitas merupakan salah satu masalah gizi yang dihadapi oleh Indonesia yang ditandai dengan status gizi lebih. ${ }^{1}$ Status gizi seseorang berkaitan dengan gambaran pola konsumsi dalam jangka waktu yang panjang. Obesitas ditandai oleh kelebihan berat badan dibandingkan dengan berat normal, yang diakibatkan oleh penimbunan lemak dalam tubuh secara berlebih. Obesitas berkaitan dengan pola konsumsi makanan tinggi kalori, gula, lemak, garam, dan rendah serat. ${ }^{2}$

Pada orang dewasa penentuan kategori berat badan dapat diukur melalui nilai Indeks Masa Tubuh (IMT). IMT merupakan alat bantu yang umum digunakan dalam memantau status gizi orang dewasa yang khususnya berkaitan dengan kekurangan atau kelebihan berat badan. ${ }^{3}$ Ambang batas IMT dengan kategori kurus 
$<18,5$, normal $18.5-25$, gemuk $25-27$, dan obesitas $>27 .^{4}$

Untuk jangka panjang, obesitas akan menyebabkan timbulnya berbagai penyakit yang terkait dengan metabolisme (metabolism syndrome) seperti diabetes melitus, hipertensi, dislipidemia, dan jantung koroner. Peningkatan risiko terhadap berbagai penyakit metabolik mengakibatkan seseorang harus mendapat perawatan kesehatan, selain itu juga dapat menurunkan aktivitas, bahkan kematian. ${ }^{5}$

Beberapa faktor penyebab obesitas antara lain gaya hidup, pola makan, dan aktivitas fisik. Perubahan gaya hidup yang lebih modern memengaruhi pola konsumsi individu yang cenderung lebih banyak mengkonsumsi makanan cepat saji yang umumnya tinggi lemak dan gula, tetapi rendah serat. Selain itu, aktivitas fisik individu cenderung berkurang akibat kemajuan teknologi. Kemudahan akses teknologi dapat berdampak negatif bagi masyarakat karena segala sesuatu saat ini dapat diperoleh dengan cara yang mudah dan praktis tanpa harus bergerak, misalnya membeli makanan cepat saji melalui layanan penyedia jasa transportasi secara daring. Kurangnya aktivitas fisik dengan pola konsumsi makanan tinggi lemak dan gula merupakan penyebab terjadinya seseorang mengalami gizi lebih (obesitas). ${ }^{6}$

Prevalensi obesitas pada balita mencapai $11,9 \%$, obesitas pada kelompok usia 5 - 12 tahun mencapai angka 8,8\%, pada kelompok usia 13 - 15 tahun sebesar $2,5 \%$, kelompok usia $16-18$ tahun yaitu $1,6 \%$, dan kelompok usia $>18$ tahun mencapai $15,4 \%{ }^{1}$ Berdasarkan pengukuran IMT dari 1.938.628 orang di Provinsi Jawa Tengah diperoleh persentase obesitas mencapai angka $28,97 \%$ yang terdiri atas 148.295 laki-laki dan 413.447 perempuan. Tingkat obesitas tertinggi berada di Provinsi Jawa Tengah, khususnya di Kota Salatiga dengan 561.621 kasus $(71,18 \%)$ obesitas. ${ }^{7}$

Pada usia lanjut (lansia), fungsi fisiologis akan mengalami penurunan akibat proses degeneratif (penuaan), sehingga dapat mendorong terjadinya penyakit tidak menular. Faktor yang turut mempengaruhi kesehatan lansia adalah kebiasaan makan tidak sehat yang dilakukan di masa lampau, sehingga pada masa ini berpengaruh pada rentannya terhadap berbagai penyakit. Prevalensi obesitas sentral tingkat nasional untuk lansia adalah 18,8\% yang tercatat dari kelompok umur 55 - 64 tahun 23,1\%, $65-74$ tahun 18,9\%, dan $>75$ tahun $15,8 \%$. Prevalensi obesitas yang paling tinggi terjadi pada kelompok usia 55-64 tahun. ${ }^{8}$

Penimbunan lemak akan menyebabkan gangguan pernafasan dan gangguan fungsi endokrin yang berisiko terhadap penyakit degeneratif seperti hipertensi, jantung koroner, dan diabetes mellitus. Kondisi tersebut akan berpengaruh terhadap rendahnya kualitas hidup dan tingginya beban ekonomi. ${ }^{9}$ Data prevalensi obesitas saat ini mengacu pada data Riset Kesehatan 
tahun 2013, sedangkan data prevalensi obesitas terbaru untuk tahun 2017 belum dapat diperoleh laporan secara resminya. Oleh sebab itu penelitian ini penting untuk dilakukan sebagai data dasar yang dapat memberikan informasi mengenai kejadian obesitas pada kelompok usia lanjut di Kota Salatiga sebagai acuan pelaksanaan program kesehatan masyarakat untuk mencegah dan mengurangi angka kejadian obesitas di Indonesia dan mengkaji faktor penyebab kejadian obesitas.

\section{BAHAN DAN CARA PENELITIAN}

Penelitian ini menggunakan penelitian survei observasional yakni metode pengumpulan data dengan mengamati lingkungan dan perilaku responden dengan pendekatan kuantitatif. Responden penelitian adalah lansia yang melakukan pemeriksaan klinis di Puskesmas Sidorejo Kidul, Kota Salatiga. Kriteria inklusi yang digunakan adalah responden kategori pra-lansia 45 - 59 tahun, lanjut usia 60 - 69 tahun, dan usia lanjut $\geq 70$ tahun baik laki-laki dan maupun perempuan, memiliki status gizi obesitas (berdasarkan IMT), pernah memeriksakan diri dan secara rutin mengikuti pemeriksaan diri minimal 3 kali selama periode tahun 2017 ke Posyandu Lansia di wilayah kerja Puskesmas Sidorejo Kidul, Kota Salatiga, serta bersedia menjadi responden untuk penelitian ini.

Penelitian ini dilakukan pada 25 kelompok posyandu yang dibina oleh Puskesmas Sidorejo Kidul Salatiga. Jumlah lansia dari 25 kelompok posyandu yang aktif dalam kegiatan yaitu 822 orang. Responden yang diperoleh sesuai dengan kriteria inklusi 89 orang $(10,8 \%)$. Penelitian dilaksanakan pada bulan Februari - April 2018.

Data yang digunakan berasal dari data primer dan data sekunder. Pengumpulan data primer dilakukan dengan melakukan observasi, pengisian kuesioner, meliputi karakteristik responden, pengetahuan responden terkait obesitas, dan pola konsumsi responden dengan pengisian Food Frequency (FFQ), serta wawancara semi terstruktur guna melengkapi informasi yang diberikan oleh para responden. Perolehan data sekunder berasal dari hasil pencatatan dan pelaporan Posyandu Lansia di Puskesmas Sidorejo Kidul, Kota Salatiga. Untuk mengetahui status gizi lanjut usia digunakan perhitungan rumus Indeks Massa Tubuh (IMT) dan pengukuran lingkar perut.

Kuesioner penelitian yang dibuat oleh peneliti telah melalui tahapan uji validitas dan realibilitas di Puskesmas Tegalrejo Kota Salatiga. Kuesioner variabel pengetahuan meliputi pemahaman responden mengenai Pedoman Gizi Seimbang (PGS) dihubungkan dengan kajian obesitas, sedangkan untuk variabel kebiasaan makan meliputi frekuensi makan, jenis makanan yang dikonsumsi, konsumsi makanan cepat saji, dan konsumsi serat. Analisis data yang digunakan meliputi uji bivariat dengan uji korelasi Spearman untuk mengetahui hubungan dari variabel 
pengetahuan dengan variabel kebiasaan makan terhadap kejadian obesitas.

\section{HASIL DAN PEMBAHASAN}

Gambaran karakteristik responden dapat dilihat pada tabel 1.

Tabel 1. Karakteristik Responden ( $\mathrm{N}=89$ )

\begin{tabular}{ccc}
\hline \multicolumn{1}{c}{ Kategori } & $\begin{array}{c}\text { Frekuensi } \\
\text { (f) }\end{array}$ & $\begin{array}{c}\text { Persentase } \\
(\%)\end{array}$ \\
\hline $\begin{array}{c}\text { Jenis Kelamin } \\
\text { Laki-laki }\end{array}$ & 6 & \\
Perempuan & 83 & 6,74 \\
Usia & & 93,26 \\
45-59 tahun & 41 & 46,07 \\
$60-69$ tahun & 42 & 47,19 \\
$>70$ tahun & 6 & 6,74 \\
Pendidikan & & \\
Tidak sekolah & 32 & 35,96 \\
SD & 18 & 20,22 \\
SMP & 13 & 14,61 \\
SMA & 24 & 26,97 \\
PT & 2 & 2,25 \\
& & \\
Pekerjaan & & \\
Petani & 1 & 1,12 \\
Peternak & 1 & 1,12 \\
Pedagang & 20 & 22,47 \\
Guru & 9 & 10,11 \\
Karyawan & 15 & 16,85 \\
Wiraswasta & 11 & 12,36 \\
Pensiunan & 4 & 4,49 \\
IRT & 28 & 31,46 \\
\hline Sumber : Data Prine
\end{tabular}

Sumber : Data Primer 2018

Berdasarkan Tabel 1, dapat diketahui bahwa mayoritas responden adalah perempuan $(93,26 \%)$, berada dalam rentang usia 60 - 68 (47,19\%), tidak sekolah $(35,96 \%)$, dan merupakan ibu rumah tangga $(31,46 \%)$.

Berdasarkan tabel 2, dari 89 responden terdapat 27 orang $(30,34 \%)$ yang memiliki riwayat penyakit hipertensi, 16 orang $(17,98 \%)$ memiliki riwayat penyakit asam urat, 12 orang $(13,48 \%)$ memiliki riwayat penyakit kolesterol, 4 orang $(4,49 \%)$ masing- masing memiliki riwayat penyakit diabetes melitus (DM) dan riwayat penyakit jantung.

Tabel 2. Riwayat Penyakit Responden

\begin{tabular}{lcc}
\hline Penyakit & $\begin{array}{c}\text { Frekuensi } \\
(\mathbf{f})\end{array}$ & $\begin{array}{c}\text { Presentase } \\
(\%)\end{array}$ \\
\hline Hipertensi & 27 & 30,34 \\
Asam urat & 16 & 17,98 \\
Kolesterol & 12 & 13,48 \\
DM & 4 & 4,49 \\
Jantung & 4 & 4,49 \\
\hline
\end{tabular}

Tabel 3. Distribusi Frekuensi Makan berdasarkan Jenis Makanan yang sering dikonsumsi

\begin{tabular}{lcc}
\hline $\begin{array}{c}\text { Bahan } \\
\text { Makanan }\end{array}$ & Jenis Makanan & Frekuensi (n) \\
\hline $\begin{array}{l}\text { Makanan } \\
\text { Pokok }\end{array}$ & $\begin{array}{c}\text { Nasi } \\
\text { Tepung terigu \& } \\
\text { singkong }\end{array}$ & $\begin{array}{c}14 \mathrm{kali} / \text { minggu } \\
\text { Lauk } / \text { minggu }\end{array}$ \\
$\begin{array}{l}\text { Hewani } \\
\text { Lauk }\end{array}$ & Tahu \& tempe & $2 \mathrm{kali} /$ minggu \\
Nabati & $11 \mathrm{kali} /$ minggu \\
Sayur & Sawi & $3 \mathrm{kali} /$ minggu \\
& Bayam & $2 \mathrm{kali} /$ minggu \\
Buah- & Pisang & $3 \mathrm{kali} /$ minggu \\
buahan & Pepaya & $2 \mathrm{kali} /$ minggu \\
Minuman & Air Putih & $14 \mathrm{kali} /$ minggu \\
& Teh & $3 \mathrm{kali} /$ minggu \\
Selingan & Gorengan & $2 \mathrm{kali} /$ minggu \\
Lemak & Minyak kelapa & $9 \mathrm{kali} /$ minggu \\
& Santan & $2 \mathrm{kali} /$ minggu \\
Pemanis & Gula pasir & $11 \mathrm{kali} /$ minggu \\
& Gula jawa & $7 \mathrm{kali} /$ minggu \\
\hline
\end{tabular}

Berdasarkan Tabel 3, dapat diketahui kebiasaan makan dari 89 responden dari bahan makanan pokok yaitu nasi 14 kali/minggu serta tepung terigu dan singkong $3 \mathrm{kali} /$ minggu. Bahan makanan lauk hewani ayam dan telur dikonsumsi 2 kali/minggu. Lauk nabati tahu dan tempe merupakan bahan makanan yang paling sering dikonsumsi sebanyak $11 \mathrm{kali} / \mathrm{minggu}$. Sayur yang paling sering dikonsumsi yaitu sawi ( 3 
kali/minggu) dan bayam (2 kali/minggu). Buah-buahan yang paling sering dikonsumsi yaitu pisang ( $3 \mathrm{kali} /$ minggu) dan pepaya ( 2 kali/minggu). Air putih dikonsumsi 14 kali/minggu dan teh $3 \mathrm{kali} /$ minggu. Gorengan merupakan selingan yang paling sering dikonsumsi yakni 2 kali/minggu. Responden mengkonsumsi bahan sumber lemak yaitu minyak kelapa $9 \mathrm{kali} /$ minggu dan santan 2 kali/minggu. Pemanis yang paling sering digunakan dalam memasak yaitu gula pasir (11 kali/ minggu) dan gula jawa (7 kali/minggu).

Tabel 4. Hasil Pengetahuan Responden

\begin{tabular}{lcc}
\hline $\begin{array}{l}\text { Tingkat } \\
\text { Pengetahuan }\end{array}$ & $\begin{array}{c}\text { Frekuensi } \\
(\mathbf{f})\end{array}$ & $\begin{array}{c}\text { Presentase } \\
(\%)\end{array}$ \\
\hline Baik & 16 & 18 \\
Cukup & 62 & 69,7 \\
Kurang & 11 & 12,3 \\
\hline Total & 89 & 100 \\
\hline
\end{tabular}

Hasil pengetahuan responden pada Tabel 4 menunjukkan bahwa 69,7\% responden memiliki pengetahuan yang cukup terhadap Pedoman Gizi Seimbang (PGS). Pedoman Gizi Seimbang (PGS) kerap disampaikan oleh para kader maupun Ahli Gizi di Puskesmas maupun Posyandu setempat. Hanya 18\% responden yang mampu memahami Pedoman Gizi Seimbang (PGS) dengan baik dan 12,3\% pengetahuan responden berada pada kategori kurang.
Tabel 5. Hasil Uji Korelasi Aspek Pengetahuan dengan Kebiasaan Makan Correlations

\begin{tabular}{llr}
\hline \multirow{7}{*}{ Pengetahuan } & $\begin{array}{c}\text { Kebiasaan } \\
\text { Makan }\end{array}$ \\
& Spearman's & -.037 \\
& rho Correlation & \\
& Sig. (2-tailed) & .733 \\
& $\mathrm{~N}$ & 89 \\
\hline
\end{tabular}

Hasil uji korelasi terhadap variabel pengetahuan obesitas dan kebiasaan makan responden diperoleh hasil bahwa tidak ada hubungan yang berarti secara statistik di antara kedua variabel tersebut $(r=-0.37$, $p>0,05)$ dan bermakna negatif.

\section{Faktor yang Mempengaruhi Kejadian Obesitas}

Berdasarkan hasil penelitian, dari 89 reponden status gizi obesitas lebih banyak dialami oleh perempuan (93,26\%) dibandingkan dengan laki-laki (6,74\%). Hal ini sesuai dengan data Riskesdas pada tahun 2013 yang menyatakan bahwa angka obesitas pada perempuan lebih tinggi dibandingkan dengan laki-laki. ${ }^{1}$.

Obesitas dipengaruhi oleh beberapa faktor yaitu faktor sosial, gaya hidup, kebiasaan makan, genetik, dan aktivitas fisik. ${ }^{10}$ Faktor yang mempengaruhi obesitas salah satunya adalah jenis kelamin. Kejadian obesitas pada perempuan lebih tinggi dibandingkan dengan laki-laki yang dipengaruhi oleh tingginya aktivitas fisik. Perempuan memiliki aktivitas yang lebih rendah dibandingkan dengan laki-laki. Disisi lain pada fase menopause perempuan akan mengalami perubahan hormon yang 
mengakibatkan peningkatan distribusi lemak tubuh. ${ }^{11}$

Pada kategori lanjut usia, tubuh akan mengalami penurunan massa otot dan perubahan hormon sehingga terjadi penurunan metabolisme dalam tubuh. Pada kategori usia ini cenderung mengalami penurunan fungsi organ tubuh akibat proses degeneratif (penuaan) sehingga dapat mendorong terjadinya penyakit tidak menular. Faktor yang turut mempengaruhi kesehatan lansia adalah kebiasaan makan tidak sehat yang dilakukan di masa lampau sehingga pada masa ini berpengaruh pada rentannya terhadap berbagai penyakit. Penurunan fungsi fisiologis berdampak pada menurunnya aktivitas fisik sehingga kemungkinan untuk terjadi obesitas lebih besar. $^{8}$

Prevalensi obesitas yang tinggi dapat dipengaruhi oleh tingkat pendidikan. Tingkat pendidikan seseorang berpengaruh terhadap tingkat pengetahuan gizi seseorang. Pengetahuan yang baik akan mendorong seseorang untuk dapat berperilaku sehat dalam memilih makanan, sehingga risiko obesitas rendah. Tingkat pendidikan yang rendah berpotensi meningkatkan jumlah kejadian obesitas di masyarakat. ${ }^{12}$

Faktor risiko lainya terhadap kejadian obesitas yaitu pekerjaan. Pekerjaan dengan aktivitas fisik yang rendah akan menjadi peluang penimbunan lemak di dalam tubuh. Pekerjaan dengan aktivitas rendah seperti guru, pedagang, IRT dan seorang pensiunan yang pada umumnya memiliki aktivitas duduk lebih banyak. Berbeda dengan pekerjaan seperti petani, peternak, karyawan dan wiraswasta yang memiliki aktivitas yang tinggi akan mengeluarkan energi lebih banyak. Seseorang dengan pekerjaan sebagai pedagang dan IRT memiliki kebiasaan olahraga yang rendah, tetapi seseorang dengan pekerjaan sebagai TNI/POLRI, PNS dan karyawan memiliki kebiasaan olahraga yang cukup baik. ${ }^{13}$

Salah satu faktor lainnya yang menjadi penyebab obesitas yaitu aktivitas fisik. ${ }^{14}$ Seseorang dengan aktivitas fisik sedang mempunyai kecenderungan menjadi obesitas sebesar 29,824 kali dibandingkan dengan seseorang dengan aktivitas tinggi. ${ }^{15}$ Pada kategori usia lanjut juga diperlukan aktivitas fisik yang cukup untuk mencegah peningkatan berat badan yang signifikan. Pada usia lanjut yang masuk dalam kategori obesitas dapat menjadikan aktivitas fisik (olahraga) sebagai alat untuk membantu menurunkan berat badan secara bertahap. Melakukan aktivitas fisik $3-5 \mathrm{kali} / \mathrm{minggu}$ dapat membantu seseorang untuk menurunkan berat badan secara bertahap dan menjaga berat badan agar tetap stabil. Perencanaan aktivitas yang baik dapat membantu pengeluaran energi dan pembakaran energi melalui setiap gerakan yang dilakukan. ${ }^{16}$

\section{Kebiasaan Makan}

Obesitas dipengaruhi oleh buruknya kebiasaan makan terutama konsumsi 
makanan yang melebihi batas kebutuhan. Konsumsi makanan dengan kandungan gula, garam, dan tinggi lemak pada kategori usia lanjut akan meningkatkan risiko terjadinya penyakit hipertensi, kolesterol, stroke, jantung koroner, diabetes melitus dan asam urat. Oleh karena itu asupan makanan pada kategori usia lanjut harus perlu diperhatikan dengan cara mengatur pola makan dengan baik. ${ }^{11}$ Berdasarkan penelitian yag telah dilakukan, penyakit yang paling banyak dialami oleh responden yaitu hipertensi $(30,34 \%)$, asam urat $(17,98 \%)$, kolesterol $(13,48 \%)$, diabetes dan jantung masingmasing sebanyak $4,49 \%$.

Tingginya asupan karbohidrat pada seseorang dengan frekuensi dan porsi makan berlebih dapat berdampak pada penumpukan lemak didalam tubuh. Berdasarkan hasil $F F Q$, jenis makanan pokok yang paling sering dikonsumsi yaitu nasi (14 kali/minggu) dengan rata-rata 1,5 centong/sekali makan, tepung terigu dan singkong (3 kali/minggu) dengan rata-rata 3 sdm dan 2 potong/sekali makan. Bahan makan lauk hewani ayam dan telur dikonsumsi 2 kali/minggu. Kementrian Kesehatan menyatakan bahwa anjuran konsumsi protein hewani yakni 2-4 potong/hari. Lauk nabati tahu dan tempe merupakan bahan makanan yang sering dikonsumsi sebanyak 11 kali/minggu. Anjuran konsumsi lauk nabati normal yaitu 24 potong/hari. ${ }^{17}$
Sayur yang paling sering dikonsumsi yaitu sawi dan bayam rata-rata 100 gram/sekali makan. Buah-buahan yang paling sering dikonsumsi yaitu pisang dan pepaya dengan rata-rata 100 gram/sekali makan. Berdasarkan asupan sayur dan buah, reponden belum dapat memenuhi standar kebutuhan serat. Badan Kesehatan Dunia (WHO) secara umum menganjurkan konsumsi sayuran 250 gram/hari dan buahbuahan 150 gram/hari untuk hidup sehat. Kandungan serat pada sayur dan buah dapat membantu tubuh untuk menghambat penyerapan gula dan kolesterol sehingga membantu meningkatkan kesehatan usia lanjut.

Gorengan merupakan selingan yang paling sering oleh responden dikonsumsi 2 kali/minggu. Responden gemar mengkonsumsi makanan yang diolah dengan minyak kelapa dan santan. Responden memiliki tingkatan asupan konsumsi makanan berlemak/minyak yang tergolong lebih. Berdasarkan hasil Riskesdas (2010), rata-rata konsumsi lemak di Indonesia yang dianjurkan yaitu 47 gram/hari atau 25\% dari total konsumsi energi. Kebiasaan konsumsi makanan berlemak > $7 \mathrm{kali} /$ minggu memiliki risiko obesitas 1.213 kali dibandingkan dengan seseorang dengan konsumsi makanan merlemak $<7$ kali/minggu. ${ }^{13}$ Seseorang yang mengkonsumsi lemak/minyak lebih dari 67 gram (5 sendok makan/hari) akan meningkatkan risiko 
hipertensi, stroke, diabetes, dan serangan jantung. ${ }^{18}$

Pemanis yang paling sering digunakan dalam memasak yaitu gula pasir dan gula jawa dengan rata-rata 3 sedok makan dan 100 gram/perhari. Konsumsi gula lebih dari 50 gram/hari (4 sendok makan/hari) akan menyebabkan obesitas dan timbulnya penyakit metabolik. ${ }^{13}$ Gula yang dikonsumsi melebihi batas kebutuhan dapat menyebabkan peningkatan berat badan. Dalam jangka panjang, konsumsi gula secara berlebih akan berdampak pada timbulnya penyakit diabetes tipe 2. Gula yang dikonsumsi oleh masyarakat tidak hanya terdapat didalam gula tebu, gula jagung dan gula aren melainkan juga terdapat didalam makanan yang mengandung karbohidrat sederhana (tepung, roti, buah dan makanan lainnya). ${ }^{16}$

Berdasarkan hasil analisis diperoleh nilai korelasi ( $r$ ) sebesar $-0,42$ yang berarti tidak adanya hubungan antara pengetahuan dengan kebiasaan makan pada lansia di Posyandu Hasil penelitian ini dipengaruhi oleh perilaku reponden yang masih tinggi mengkonsumsi makanan yang berlemak, tinggi gula, dan tinggi karbohidrat, sedangkan sebenarnya responden sudah memiliki pengetahuan terhadap makanan apa saja yang seharusnya dibatasi pada kategori lanjut usia. Tingkat pengetahuan yang tinggi belum tentu membuat seseorang mempraktikkan pengetahuan yang dimiliki dalam kehidupan sehari-hari.
Tidak terdapat hubungan antara pengetahuan dengan kebiasaan makan pada responden dapat dipengaruhi oleh kebiasaan makan responden dalam menentukan pilihan makanan. Kebanyakan lansia memilih bahan makan yang mudah ditemui dan diolah tanpa memperhitungkan kebutuhan dan batasanbatasan dalam mengkonsumsi makanan dengan kandungan tinggi gula, lemak dan garam. Berdasarkan penelitian yang telah dilakukan, reponden sering mengkonsumsi lauk hewani dan nabati dengan olahan digoreng. Selain itu selingan yang paling sering dikonsumsi yaitu gorengan. Konsumsi pemanis seperti gula pasir dan gula jawa juga sering.

Faktor lain yang dapat mempengaruhi obesitas yaitu peran keluarga, adanya keluarga dalam pamenuhan kebutuhan nutrisi lansia juga akan mempengaruhi kesehatan lansia. Sebanyak 80,6\% dukungan keluarga sangat penting dalam pemenuhan nutrisi lansia. ${ }^{19}$ Kesejahteraan keluarga juga menjadi pengaruh terjadinya obesitas pada lanisa. Lansia dengan status gizi obesitas memiliki perilaku makan yang kurang baik. Berdasarkan hasil survei lansia yang tinggal dengan keluarga cenderung memperoleh ketersediaan makan yang lebih baik dibandingkan dengan yang tidak tinggal dengan keluarga. Untuk memperoleh status gizi yang cukup keluarga harus membantu dalam mengatur dan menjaga pola makan serta kebiasaan makan lansia. Dengan pengetahuan yang baik dan penerapan 
mengenai pola makan serta kebiasaan makan pada keluarga akan membantu lansia dalam memperoleh nutrisi yang cukup. ${ }^{19}$

Sosial ekonomi merupakan salah satu penyebab terjadinya terjadinya obesitas. Seseorang dengan pendapatan tinggi akan maka berpeluang lebih besar dalam memenuhi kebutuhan termasuk pemenuhan dalam nutrisi. Semakin besar pendapatan seseorang akan berpengaruh pada tingkat daya beli makanan sehingga semakin besar pula kemungkinan terjadinya obesitas. ${ }^{20}$

\section{KESIMPULAN}

Angka kejadian obesitas pada lansia di wilayah kerja Puskesmas Sidorejo Kidul Kota Salatiga mencapai 10,8\% pada periode pengamatan Februari hingga April 2018. Angka kejadian obesitas pada perempuan lebih tinggi dibandingkan dengan laki-laki. Tidak terdapat hubungan antara tingkat pengetahuan dan kebiasaan makan sehingga dapat dianalisa faktor lain penyebab terjadinya obesitas yaitu faktor usia, jenis kelamin, pendidikan, pekerjaan, sosial ekonomi, dan peran keluarga.

\section{TERIMA KASIH}

1. Dinas Kesehatan Kota Salatiga

2. Puskesmas Sidorejo Kidul, Kota Salatiga dan Posyandu Lansia di wilayah Kerja Puskesmas Sidorejo Kidul

\section{KEPUSTAKAAN}

1. Kementrian Kesehatan RI. Riset
Kesehatan Kementrian Kesehatan RI. Jakarta. 2013
2. Sukma D.C., Ani M. Hubungan Pengetahuan dan Sikap dalam Memilih Makanan Jajanan dengan Obesitas pada Remaja di SMP Negeri 2 Brebes. Journal of Nutrition College. 2014; Volume 3, (4), Hal. 862-870.

3. Departemen Kesehatan Republik Indonesia (Depkes). Profil Kesehatan Indonesia. Jakarta. 1994

4. Pedoman Gizi Seimbang. Peraturan Menteri Kesehatan Republik Indonesia Nomor 41 Tahun 2014. Kementerian Kesehatan RI. 2014

5. Chan R.S.M, Woo J. Prevention of Overweight and Obesity: How Effective is the Current Public Health Approach. Int J Environ Res Public Health. 2016; Volume 7, (3), Hal. 765-783.

6. Peltzer K, Pengpid S, Gasparishvili A. Prevalence of Overweight/Obesity and Its Associated Factors among University Students from 22 Countries. Int J Environ Res Public Health 11(7):7425-7441. 2014.

7. Dinas Kesehatan Provinsi Jawa Tengah. Profil Kesehatan Provinsi Jawa Tengah. Semarang. 2015

8. Pusat Data dan Informasi Kementrian Kesehatan. Gambaran Kesehatan Lanjut Usia Di Indonesia. Buletin Jendela Data Dan Informasi Kesehatan: Jakarta. 2013

9. Departemen Kesehatan Republik Indonesia. Sistem Kesehatan Nasional 2004. Jakarta. 2004

10. Murray R, Granner D.K., Rodwell V.W. Biokimia. Jakarta: Buku Kedokteran EGC. 2009

11. Janghorbani M., Masound A., Walter C.W., Gouya M.M., Alireza D., Siamak A., Alireza M. First Nationwide Survey of Prevalence of Overweight, Underweight, and Abdominal Obesity in Iranian Adults. Obesity a Res J. 2007; Volume 15, (11), Hal. 2797-2808.

12. Sugianti E.H, Afriansyah N. Faktor Risiko Obesitas Sentral pada Orang Dewasa di DKI Jakarta: Analisis Lanjut Data Riskesdas. Jakarta: Gizi Indon. 2009; Volume 32, (2), Hal. 105-116.

13. Rahmawati S. Faktor-faktor yang Berpengaruh terhadap Status Gizi Obesitas Orang Dewasa di Kota Depok 
Tahun 2007. Gizi Indon. 2008; Volume 31, (1), Hal. 35-48.

14. Almatsier S, Soetardjo S, Soekarti M. Gizi Seimbang dalam Daur Kehidupan. Jakarta: Gramedia Pustaka Utama. 2011

15. Kurniawati Y, Rudi F, Fahrini Y. Hubungan antara Pola Makan, Asupan Energi, Aktivitas Fisik, dan Durasi Tidur dengan Kejadian Obesitas pada Polisi. Jurnal Publikasi Kesehatan Masyarakat Indonesia. 2016; Volume 3, (3), Hal. 112117.

16. Kementerian Kesehatan RI. Peraturan Menteri Kesehatan nomor 41 tahun 2014 Pedoman Gizi Seimbang. Jakarta. 2014

17. Departemen Kesehatan RI. Profil Kesehatan Indonesia 2015. Jakarta: Departemen Kesehatan RI. 2015
18. Kementerian Kesehatan RI. Peraturan Menteri Kesehatan nomor 30 tahun 2013 tentang Pencantuman Informasi Kandungan Gula, Garam dan Lemak serta Pesan Kesehatan untuk Pangan Olahan dan Pangan Siap Saji. Jakarta. 2013

19. Nazari N, Yusuf R, Tahlil T. Dukungan dan Karakteristik Keluarga dengan Pemenuhan Nutrisi pada Lansia. Jurnal Keperawatan. 2016; Volume 4, (2), Hal. 75-86.

20. Rosdiana, A.L. Pengaruh Demografi, Sosial-Ekonomi, Gaya Hidup, Status Gizi dan Kesehatan terhadap Obesitas Sentral pada Ibu Rumah Tangga. Bogor: Institut Pertanian Bogor. 2014 